than four-fold. In the Coxsackie system reductions up 80 -fold were found.

Secondary immune responses were elicited in measlesimmune persons by injection of inactivated measles vaccine. Following immunization $7 S$ antibodies increased, but no $19 S$ antibodies were detectable. Thus, the primary or secondary character of an antibody rise may be determined.

I thank Dr. Samuel Karelitz, Dr. Francis Black and Dr. Mary Gabrielson for providing many of the patients' sera tested.

The work was supported in part by the U.S. Public Health Service research grant $A I-04776$ from the Institute of Allergy and Infectious Diseases.

\section{ANN SchLUEDERBERG}

Department of Epidemiology and Public Health, Yale University School of Medicine, New Haven.

${ }^{1}$ Uhr, J. W., and Finkelstein, M. S., J. Exp. Med., 117, 3, 457 (1963).

${ }^{2}$ Svehag, S., and Mandel, B., J. Exp. Med., 119, 1, 21 (1964).

${ }^{3}$ Smith, R. T., Ciba Found. Symp. Cellular Aspects Immunity, 348 (1960).

Rosen, L., Virology, 13, 139 (1961).

E Ellis, E. F., and Smith, R. T., Southern Med. J., 56, 1449 (1963).

\section{Simplified Procedure for ' 'assive Haemag- glutination Tests with Protein Antigens}

For passive haemagglutination tests with proteins, it has been necessary to couple these antigens to erythrocytes by agents such as bis-diazotized benzidine ${ }^{1-3}$, tolylone-2,4-diisocyanate ${ }^{4}$ and tannic acid ${ }^{5}$. During the course of investigations with formalin-treated erythrocytes, we observed that bovine serum albumin (BSA) would adsorb on formalin-treated chicken erythocytes (FCE), as well as on formalin-treated sheep erythrocytes (FSE) without recourse to such coupling agents. This finding suggested a means of simplifying the procedure for coating erythrocytes with proteins for passive haemagglutination tests.

When protein antigens are adsorbed on tannic acidtreated erythrocytes, Coombs's serum cannot be used since globulins of the antiserum are non-specifically adsorbed. This is overcome by preliminary incubation of the coated, tanned erythrocytes with normal serum of a different species from that providing the direct antiprotein serum ${ }^{6}$. The present method is advantageous in that Coombs's serum reacts specifically with the coated erythrocytes that have previously reacted with specific anti-protein serum and greatly augments the sensitivity of the test. Chicken erythrocytes were obtained from White Leghorn hens 20 weeks old. FCE were prepared according to the method of Weinbach ${ }^{7}$ and resuspended in $0 \cdot 1 \mathrm{M}$ acetate buffer, $p \mathbf{H} 5 \cdot 0$. FCE were coated with BSA by mixing $5 \mathrm{ml}$. of 2 per cent $\mathrm{FCE}$ suspension with $5 \mathrm{ml}$. of acotate buffor containing $1 \mathrm{mg}$ of BSA and the mixture was kept at $24^{\circ} \mathrm{C}$ for $4 \mathrm{~h}$ with constant rotation. The cells were then washed 3 times and resuspended in $0.1 \mathrm{M}$ phosphate buffer, $p \mathbf{H} \mathbf{7 \cdot 2}$, as a 1 per cent suspension.

Haemagglutination tests were performed by incubating, for $1 \mathrm{~h}$, mixtures of $0.1 \mathrm{ml}$. of 1 per cent BSA-coated FCE and $0.1 \mathrm{ml}$. of appropriate dilutions of chicken anti-BSA
Table 2. Specific Inhibition of Hakmagelutination Reaction of BSA-COATED FCE BY BSA

Anti-BSA serum was incubated with BSA or HGG followed by addition of BSA-coated FCE. After recording the titre, Coombs's serum was added.

\begin{tabular}{lcc} 
BSA added & \multicolumn{2}{c}{ Antiserum dilution titre } \\
Bfter Coombs's \\
None & $1 / 400$ & $1 / 40,000$ \\
$0 \cdot 03 \mu \mathrm{g}$ & $1 / 120$ & $1 / 12,000$ \\
$0 \cdot 1 \mu \mathrm{g}$ & $1 / 120$ & $1 / 12,000$ \\
$1 \cdot 0$ & $1 / 20$ & $1 / 40$ \\
$3 \cdot 0$ & $>1 / 20$ & $>1 / 20$ \\
HGG added & $1 / 400$ & $1 / 40,000$ \\
$500 \mu \mathrm{g}$ & $1 / 400$ &
\end{tabular}

serum diluted in phosphate buffer containing 2 per cent normal rabbit serum. After the agglutination reactions were recorded, $0.1 \mathrm{ml}$. of Coombs's serum (rabbit antichicken $\gamma$-globulin serum) was added, the tubes were shaken and then incubated for an additional hour. As shown in Table 1, before and after the addition of Coombs's serum, the chicken antiserum used gave titres of $1 / 600$ and $\mathrm{I} / 60,000$, respectively. FCE coupled with BSA via bis-diazotized benzidine gave the same antiserum titres.

Inhibition of the reaction by BSA, but not by human $\gamma$-globulin (HGG), attests to the specificity of the reaction. BSA in amounts ranging from 0.01 to $3 \mu \mathrm{g}$ were incubated with $0.1 \mathrm{ml}$. of the antisorum for $0.5 \mathrm{~h} ; 0.1 \mathrm{ml}$. of the reaction mixture was then reacted with $0.1 \mathrm{ml}$. of coated FCE. The data in Table 2 show that the reaction with antiserum was completely inhibited by $3 \mu \mathrm{g}$ of BSA whereas even $500 \mu \mathrm{g}$ of HGG was without effect.

Preliminary experiments have shown that two other antigens would coat formalin-treated erythrocytes. Using the foregoing procedure, rabbit $\gamma$-globulin was found to coat FCE as well as FSE. Ovalbumin coated FCE at $p \mathrm{H} 4$ but not at $p \mathrm{H} 5$.

Arthur A. Hirata

Philip W. Stashak

Laboratory of Immunology,

National Institute of Allergy

and Infectious Diseases,

Bethesda, Maryland.

${ }^{1}$ Pressman, D., Campbell, D. H., and Pauling, L., J. Immunol., 44, 101 (1942).

' Daniel, T. M., Weyland, J. G. M., and Stavitsky, A. B., J. Immunol., 90, 741 (1963).

s Butler, W. T., J. Immunol., 90, 663 (1963).

Gyenes, L., and Sehon, A. H., Immunochemistry, 1, 43 (1964).

${ }^{5}$ Boyden, S. V., J. Exp. Med., 93, 107 (1951).

- Mathews, K. P., J. Immunol., 82, 279 (1959)

'Weinbach, R., Schweiz. Z. Path. Bakt., 21, 1043 (1958).

\section{Quantitative Estimation of the Reactivity of Normal and Hodgkin's Disease Lymphocytes with Thymidine-2-14C}

SINCE lymphoid blood cells play an important part in the mediation of delayed hypersensitivity and homograft rejection ${ }^{1-4}$, it is reasonable to expect that further understanding of these forms of immunological responsivenoss will come from appropriate in vitro investigations of circulating lymphocytes. Lymphocyte reactivity in vitro may also provide insight into the pathogenesis of diseases involving immune or autoimmune mechanisms and provide a measure of the efficacy of immunological suppression. It has been the particular goal of several laboratories $^{5-7}$ to apply such lymphocyte investigations to the

Table 1. Antiseruy dilution Titre of Chicken anti-bSA Serum agarnst bSA-coated FCE with and without Coombs's Skrom

\begin{tabular}{|c|c|c|c|c|c|c|c|c|c|c|c|c|}
\hline & \multicolumn{3}{|c|}{ Controls } & \multicolumn{9}{|c|}{ Final dilutions of anti-BSA serum } \\
\hline & Diluent & $\begin{array}{c}\text { NCS* } \\
\frac{1}{10}\end{array}$ & Coombs's & $\frac{1}{20}$ & $\frac{1}{60}$ & $\frac{1}{200}$ & $\frac{1}{600}$ & $\frac{1}{2,000}$ & $\frac{1}{8,000}$ & $\frac{1}{20,000}$ & $\frac{1}{60,000}$ & $\frac{1}{200,000}$ \\
\hline $\begin{array}{l}\text { Before Coombs's } \\
\text { After Coombs's }\end{array}$ & $\overline{-}$ & $\overline{-}$ & $\overline{-}$ & $\stackrel{+}{+}$ & + & $\begin{array}{l}+ \\
+\end{array}$ & $\begin{array}{l}+ \\
+\end{array}$ & $\overline{+}$ & $\overline{+}$ & $\bar{t}$ & $\overline{+}$ & $\overline{-}$ \\
\hline
\end{tabular}

* Normal chicken serum. 